\title{
PENDIDIKAN ISLAM MENGHADAPI TRADISI, TRANSISI, DAN MODERNISASI
}

\author{
Ahmad Shofiyuddin Ichsan ${ }^{1}$, Ichlacul Diaz Sembiring ${ }^{2}$, Naurah Luthfiah $^{3}$ \\ ${ }^{1}$ Institut Ilmu Al Qur'an An-Nur Yogyakarta, ${ }^{2,3}$ Universitas Islam Negeri Sumatera Utara Medan \\ E-mail: ahmad.shofiyuddin.ichsan@gmail.com, ichlasdiaz@gmail.com, naurahluthfiah341@gmail.com
}

How to Cite:

Ichsan, A. S., Sembiring, I. D., \& Luthfiah, N. (2020). Pendidikan Islam Menghadapi Tradisi, Transisi, Modernisasi. Fitrab: Journal of Islamic Education, 1(1). 107-123.

\section{ARTICLE HISTORY \\ Received :18 July 2020 \\ Revised :21 July 2020 \\ Accepted :22 July 2020 \\ Published :25 July 2020}

\section{KEYWORDS:}

Islamic Education,

Tradition, Transition

Modernization

\begin{abstract}
Islamic education faces many challenges in the current era of globalization. Some relate to tradition, transition and modernization, and of course Islamic education cannot avoid it. The purpose of this research is to find out how Islamic educational institutions face tradition, transition, and modernization so that their existence can still be accepted by the community and remain able to compete with nonIslamic educational institutions. The results of this study are to deal with traditions, transitions and modernization that must be carried out in Islamic education is to improve and enhance the overall education system in Islamic education institutions themselves, both in terms of the ability of teachers in the use of technology, curriculum implementation that is tailored to the needs of the community while still being emphasizing the objectives of Islamic education, carrying out various educational innovations that aim to improve student learning, so as to produce students who are smart, honest, disciplined, and remain devoted to Allah SWT.
\end{abstract}

\section{ABSTRAK}

Pendidikan Islam menghadapi banyak tantangan di era globalisasi saat ini. Beberapa di antaranya berhubungan dengan tradisi, transisi dan modernisasi. Berhubungan dengan tradisi pendidikan Islam dituntut tidak tertinggal oleh zaman, tapi di sisi lain dituntut untuk mempertahankan tradisi. Berhubungan dengan transisi, pendidikan islam harus senantiasa terus berusaha untuk berkembang dari satu sisi ke sisi lainnya. Berhubungan dengan modernisasi pendidikan islam dituntut untuk selalu melakukan pembaharuan demi memenuhi tuntutan era globalisasi. Tujuan dari penelitian ini adalah untuk mengetahui bagaimana lembaga pendidikan Islam menghadapi tradisi, transisi, dan modernisasi sehingga keberadaannya masih dapat diterima oleh masyarakat dan tetap mampu bersaing dengan lembaga pendidikan nonIslam. Hasil penelitian menunjukkan bahwa pendidikan Islam akan mampu untuk bertahan dengan kondisi apapun jika memperhatikan beberapa hal yakni peningkatan sistem pendidikan secara totalitas pada lembaga pendidikan Islam, dalam hal ini peningkatan itu berfokus pada kemampuan guru dalam penggunan teknologi, implementasi kurikulum yang disesuaikan dengan kebutuhan masyrakat sambil tetap menekankan pada tujuan pendidikan Islam, melakukan berbagai inovasi pendidikan yang bertujuan meningkatkan pembelajaran siswa sehingga menghasilkan siswa yang cerdas, jujur, disiplin, dan tetap mengabdikan diri kepada Allah SWTT. 


\section{PENDAHULUAN}

Pendidikan Islam di masa modern haruslah mampu menghadapi berbagai tantangan yang ada di depannya. Apabila masyarakat seringkali mengesampingkan pendidikan berbasis Islam apabila dibandingkan dengan dengan pendidikan Umum. Karenanya pendidikan Islam memiliki banyak tantangan termasuklah di dalamnya tantangan dalam menghadapi tradisi, transisi, dan modernisasi.

Penelitian ini dilakukan untuk mengetahui bagaimana sebuah lembaga pendidikan Islam memperjuangkan keberadaannya ditengah berbagai tantangan yang ada di zaman modern ini.

Sebuah lembaga pendidikan harus mampu berdiri di tengah tradisi yang hidup dan tumbuh di tengah masyarakat. Belum lagi di Indonesia yang hidup dengan beragam tradisi di dalamnya yang telah ada selama bertahun-tahun yang merupakan sebuah perbuatan yang diterima dan dilakukan secara terus-menerus dan dianggap sebagai warisan dari nenek moyangnya yang kerapkali kita temukan di dalamnya tidak sesuai dengan ajaran Islam.

Pendidikan Islam juga tidak terlepas dari transisi, yaitu peralihan-peralihan dalam berbagai bidang yang turut serta mempengaruhi pendidikan Islam.

Serta modernisasi, yang biasanya terjadi dalam perkembangan suatu keadaan kepada keadaan lain yang lebih baik dari sebelumnya.
Masa modern ini lembaga-lembaga pendidikan saling berusaha memberikan pelayanan sebaik mungkin untuk masyarakat dengan menumbuh kembangkan kualitas pendidikan di dalamnya. Melalui lingkungan dan kondisi lembaga-lembaga pendidikan berusaha melakukan pengelolaan pendidikan seprofesional mungkin untuk menjadikan lembaga pendidikan mereka sebagai yang paling efektif, berkualitas, maju, unggul serta diminati oleh khalayak ramai. Peran lembaga pendidikan sebagai penyedia jasa di era sekarang telah bergeser menjadi usaha untuk memberikan keuntungan material. Bertolak dari titik inilah terjadi persaingan yang sangat ketat dan menarik antar lembaga pendidikan. Walaupun seperti kita ketahui persaingan adalah sebuah fakta tak terelakkan yang selalu berlangsung dari waktu ke waktu.

Melalui berbagai cara dan strategi lembaga-lembaga pendidikan meningkatkan efektifitas dan efisiensi pengelolaannya agar mampu tetap eksis dalam bersaing dan berkompetensi dengan lembaga pendidikan lainnya. Beberapa cara yang dilakukan oleh lembaga-lembaga pendidikan untuk memenangkan kompetisi ini adalah: meningkatkan kualitas fasilitas pembelajaran, memberikan biaya yang relatif terjangkau seluruh kalangan, memperkenalkan dan memperluas jangkauan lembaga mereka melalui berbagai media, memberikan pendekatan pada beberapa tokoh 
masyarakat, menujukkan peningkatan mutu SDM para pengelola atau tenaga pendidik di dalamnya, memberikan bantuan pendidikan kepada siswa melalui pemberian beasiswa, memperbaiki lokasi bangunan, membangun dan menunjukkan citra lembaga pendidikannya dan lain sebagainya.

Persaingan ini, harus tetap disikapi oleh lembaga pendidikan Islam dengan posisif sebagai sebuah langkah untuk melalukan berbagai pengembangan yang inovatif, agar mampu ikut bersaing dengan lembaga pendidikan non-Islam. Lembaga pendidikan Islam harus mengenal target konsumennya dengan terus menggali informasi agar pengembangan dapat dilakukan sesuai dengan kebutuhan darin target konsumen yang dibidik, dengan tetap memantai strategi para pesaingnya, dan melakukan perbaikan-perbaikan pada strategi pengembangan yang diterapkan dari waktu ke waktu. Namun hal yang paling penting adalah lembaga pendidikan Islam harus melakukan pengembanganpengembangan pada lembaga pendidikannya dengan tetap bercirikan nuansa Islami, jangan sampai lembaga pendidikan Islam justru kalah nilai Islaminya dibandingkan lembaga pendidikan non Islam. Menyuguhkan nilai-nilai Islami, dengan berbagai bentuk variasi dan inovasi adalah hal mutlak yang harus dilakukan lembaga pendidikan Islam agar mampu berada di tengah-tengah persaingan lembaga pendidikan di masa modern saat ini (Indrioko 2016).

Mengetahui tantangan yang dihadapi tentu akan memudahkan lembaga pendidikan Islam untuk memahami persaingan dan mempersiapkan diri dalam menghadapi tantangan-tantangan tersebut dengan sebaik-baiknya, terutama yang berkaitan dengan tradisi, transisi, dan modernisasi yang di masa kini tentu tidak dapat dihindari.

Hal ini tentu akan berpengaruh terhadap implikasi lembaga pendidikan Islam itu sendiri ditengah-tengah masyarakat. Dimana lembaga pendidikan Islam haruslah mampu melawan dan tetap berdiri kokoh dalam menyikapi tradisi, transisi, dan modernisasi di era globalisasi saat ini, dengan tetap tidak melupakan bahwa lembaga pendidikan Islam tetap harus mampu mengikuti tuntutan, harapan, dan keinginan masyarakat. Sehingga tetap mampu bersaing dengan lembaga pendidikan umum dengan tetap tidak tertinggal baik dari segi kemajuan, kedisiplinan, isi pembelajaran, dan juga ketakwaan terhadap Allah SWT karena itulah hakikatnya sebab dilaksanakannya pendidikan Islam itu sendiri.

\section{KAJIAN TEORI}

Untuk mendukung temuan penelitian nantinya, maka akan dipaparkan beberapa teori penelitian yang berkaitan 
dengan topik penelitian, sebagaimana yang dijelaskan di baawah ini:

\section{Pendidikan Islam}

Menurut UU No.20/2003 tentang Sistem Pendidikan Nasional, pendidikan merupakan usaha sadar dan terencana dalam langkah mewujudkan suasana belajar dan proses pembelajaran yang aktif dimana peserta didik dapat mengembangan potensinya untuk memiliki kekuatan spiritual, keagamaan, pengendalian diri, kepribadian, kecerdasan, akhlak mulia, serta keterampilan yang diperlukan, dalam masyarakat, bangsa dan negara (Neolaka 2017).

Menurut Moch. Tolchah Pendidikan Islam adalah usaha-usaha yang dilakukan seorang Mukmin untuk mengembangkan potensi yang dimilikinya, baik itu berupa potensi fisik, potensi rohani, maupun potensi intelektual. Tidak seperti pemahaman para sufi yang hanya mementingkan kerohanian atau pun moralitas saja, atau seperti pendidikan dalam militer yang hanya mengkhususkan diri pada pengembangan keterampilan dan disiplin, atau seperti para filosof yang menekankan diri pada pendidikan rasio, akan tetapi pendidikan Islam lebih mementingkan pada semua potensi yang ada pada diri manusia secara seimbang, baik dari unsur ruhani, jasmani, serta unsur akal (Tolchah 2015).

Pada hakikatnya pendidikan Islam memiliki tujuan yang sama dengan alasan mengapa agama Islam itu diturunkan, yaitu untuk membentuk manusia yang muttaqin yang berdimensi infinitum (tidak terbatas jangkauan manusia), baik itu secara linier maupun algoritmik (berurutan secara logis) tetap berada pada garis mukmin-muslimmuhsin dengan masing-masing perangkat komponen, variabel, dan parameternya yang secara kualitatif bersifat kompetitif.

Karenanya tujuan pendidikan Islam dapat dipecah menjadi beberapa bagian, yaitu:

a. Sebuah usaha membentuk manusia muslim yang dapat dan selalu melaksanakan ibadah maghdah;

b. Membentuk manusia muslim yang bukan hanya melaksanakan ibadah maghdah namun juga ibadah muamalah sebagai bentuk kedudukannya sebagai makhluk sosial atau anggota masyarakat dalam lingkungan tertentu;

c. Membentuk rasa tanggung jawab kepada lingkungan sosial dan bangsanya sebagai bentuk rasa tanggung jawab kepada Allah sebagai seorang warga negara;

d. Membentuk dan mengembangan tugas sebagai tenaga profesional yang siap dan terampil untuk memasuki teknostruktur dalam masyarakat; 
e. Mengembangan diri menjadi tenaga ahli di bidang ilmu-ilmu agama dan Islami.(Feisal 1995).

Karenanya, dibandingkan dengan sistem pendidikan lainnya, pendidikan Islam memiliki karakteristik yang membedakannya dengan yang lain, diantaranya yaitu:

Pertama, pendidikan islam menekankan pada pencarian ilmu pengetahuan, penguasaan, dan pengembangan atas dasar ibadah kepada Allah SWT. Setiap orang yang beragama Islam baik laki-laki maupun perempun memiliki kewajiban untuk mencari ilmu pengetahuan yang harus dipahami secara mendalam, yang dalam pengembangannya dilakukan dalam rangka ibadah untuk kemaslahatan umat manusia pada umumnya. Pencarian, penguasaan, dan pengembangan ilmu pengetahuan dilakukan secara berkesinambungan, dan berlangsung seumur hidup, atau yang lebih dikenal dengan sebutan long life education pada sistem pendidikan modern.

Dalam pendidikan Islam upaya pencarian, penguasaan dan pengembangan ilmu pengetahuan ini sangat menekankan pada nilai-nilai akhlakul karimah. Dimana sikap jujur, tawadhu' dan menghormati sumber ilmu pengetahuan adalah prinsip yang harus dipegang pada pencari ilmu pengetahuan.

Karakteristik kedua, adalah pengakuan pada potensi dan kemampuan seorang pencari ilmu untuk berkembang. Maksudnya adalah para pencari ilmu adalah makhluk Tuhan yang perlu dihormati dan disantuni agar potensi-potensi yang dimilikinya dapat diaktulisasikan dengan baik dalam kehidupan.

Karakteristik ketiga, dalam pengamalan ilmu pengetahuan itu, para pencari ilmu mendasarinya sebagai bentuk tanggung jawab kepada Tuhan dan umat manusia. Maksudnya disini adalah bahwa ilmu pengetahuan tidak hanya terbatas untuk diketahui dan dikembangkan saja, melainkan adanya tanggung jawab untuk dipraktikkan dalam kehidupan nyata. Karenanya terdapat konsistensi antara apa yang diketahui dengan apa yang diamalkan dalam kehidupan seharihari. Mengetahui suatu ilmu sama pentingnya dengan mengamalkannya secara konkret dalam agama Islam, sebagai sebuah bentuk usaha mewujudkan kemaslahatan bagi (Azra 2012).

\section{Tradisi}

Tradisi merupakan kata yang berasal dari Bahasa Latin yaitu "traditio", sebuah kata yang dibentuk dari kata kerja "traderere" atau "trader" yang mempunyai makna mentransmisikan, menyampaikan, dan mengamankan. Sebagai sebuah nomina, kata "traditio" ini memiliki makna yaitu kebiasaan yang disampaikan secara turun temurun dan akan membutuhkan waktu lebih lama lagi. 
Ada tiga karakteristik sehingga sesuatu dapat disebut sebagai sebuah tradisi, yaitu: Pertama, tradisi harus berupa kebiasaan (lore) dan proses (process) dari kegiatan yang dimiliki bersama oleh sebuah komunitas atau lingkungan sosial. Sehingga bisa diartikan bahwa makna kontinuitas (berkelanjutan), materi, adat dan ungkapan verbal yang dimiliki bersama serta dilakukan dalam kelompok-kelompok tertentu dapat disebut sebagai sebuah tradisi. Kedua, tradisi itu merupakan sesuatu yang menciptakan dan juga mengukuhkan sebuah identitas. Memiliki tradisi akan memperkuat nilai dan keyakinan pembentukan kelompok dalam sebuah komunitas (Nofrita 2019).

Secara umum istilah tradisi dapat dirumuskan sebagai bentuk praktek dan kepercayaan yang dilakukan oleh kelompok sosial yang bertransmisikan dari masa lalu, dapat pula disebut sebagai kepercayaan, kebiasaan, yang diturunkan oleh sebuah generasi kepada generasi berikutnya, dan berlanjut seterusnya. Praktek dan kepercayaan dipandang memiliki otoritas pada zaman sekarang karena berasal dari masa lalu. Seringkali konsep ini memiliki nuansa "lisan" dalam arti tradisi yang bersifat tidak tertulis. Oleh karena itu dipahami sebagai sebuah pewarisan (passing on), pengertian tradisi secara umum juga menimbulkan persepsi bahwa tradisi bersifat abadi dan tidak berubah sepanjang masa (Tjaya 2005).
Seringkali tradisi disebut sebagai sebagian unsur dari sistem budaya yang tumbuh di masyarakat. Sehingga, tradisi sering diartikan sebagai sebuah bentuk warisan budaya nenek moyang, yang telah melewati kurun waktu ratusan tahun dan tetap eksis dilaksanakan oleh orang-orang atau individu yang lahir belakangan. Tradisi menjadi sebuah warisan nenek moyang yang diikuti karena dianggap sebagai semacam pedoman dari nenek moyang bagi yang masih hidup. Tradisi dinilai sebagai sesuatu yang sangat baik oleh kelompok sosial atau individu yang memilikinya, bahkan di beberapa kelompok sosial mereka menganggap bahwa tradisi tidak dapat diubah atau ditinggalkan. Pada beberapa negara Timur Jauh, seperti Tiongkok, Thailang, Jepang, Filipina, dan Indonesia sebagian tradisi mereka mengandung nilainilai religi di dalamnya (Simanjuntak 2016).

Pendidikan Islam tidak bisa dipisahkan dengan tradisi, begitu pula ia tidak bisa menutup diri akan modernisasi. Tradisi bukan untuk ditinggalkan begitu saja, nilai-nilai mulia dari sebuah warisan sejarah harus tetap dipertahankan, agar generasi penerus tidak kehilangan jati dirinya. Sebaliknya, tradisi dapat dijadikan modal bagi terbangunnya sebuah tradisi baru. Tradisi dalam pendidikan Islam yang dimaksud disini adalah khazanah keilmuan yang diwariskan oleh ulama terdahulu, terlebih ulama pada zaman keemasan (The 
Golden Age) Islam. Sangat disayangkan apabila generasi sekarang tidak mengenal karya ulama sekaliber Hujjatul Islam Imam Al-Ghazali, Imam Syafi'i, Al-Khawarizmi, Al-Farabi, dan lain-lain.

Pendidikan Islam di Indonesia pun tidak bisa dilepaskan dari tradisi yang dibangun oleh nenek moyang. Jika menilik sejarah, bagaimana pendidikan Islam di masa lalu mampu melahirkan generasigenerasi yang bukan hanya 'alim di bidang keagamaan, melainkan juga memiliki jiwa nasionalisme yang tinggi. Hal ini tentu haruslah menjadi sebuah tradisi yang harus dilanjutkan oleh generasi berikutnya (Kholik 2020).

\section{Transisi}

Dalam Kamus Besar Bahasa Indonesia (KBBI), transisi adalah "peralihan dari keadaan, tempat, tindakan, dan sebagainya pada yang lain” (Sugono 2019).

Bila dikaitkan dengan pendidikan, dalam menghadapi transisi sendiri, sikap orang tua dalam memilihkan pendidikan untuk anaknya terbagi kedalam tiga kecenderungan, yaitu:

a. Orang tua akan menjadikan pendidikan agama lebih penting dari pada sekolah. Sehingga walaupun terpaksa masuk lembaga pendidikan umum, akan tetap diselingi dengan pendidikan agama di pesantren.

b. Orang tua yang menjadikan lembaga pendidikan umum (terutama yang termasuk golongan sekolah favorit) sebagai tujuan utama. Dan pendidikan agama dapat dikesampingkan karena dapat diperoleh dan dipelajari melalu jalur dan media lainnya.

c. Orang tua yang mejadikan lembaga pendidikan umum dan lembaga pendidikan agama sama pentingnya. Orang tua yang termasuk golongan ini akan menghindari lembaga pendidikan yang berbasis non muslim (Amin 2015).

\section{Modernisasi}

Modernisasi merupakan kata dasar dari "modern" yang dalam Bahasa Latin disebut dengan "modernus" yang terbentuk dari kata "modo" dan "ernus". Modo memiliki arti "cara", sedangkan ernus merupakan kata yang merujuk pada adanya periode waktu masa kini. Modernisasi dapat diartikan sebagai sebuah proses menuju masyarakat modern atau masyarakat maka kini. Dapat pula diartikan sebagai bentuk perubahan masyarakat tradisional menuju masyarakat yang lebih modern. Jadi, dapatlah disimpulkan bahwa modernisasi merupakann sebuah bentuk perubahan masyarakat tradisional menuju pembaharuan diri dengan usaha untuk mendapatkan karakteristik yang terdapat pada masyarakat modern (Maryati 2007). 
Menurut Lely Noormindhawati modernisasi dapat dilihat dari ciri-ciri masyarakatnya, antara lain:

a. Sikap hidup masyarakatnya lebih terbuka, lebih siap untuk menerima hal-hal baru dan lebih cepat melakukan perubahan sehingga perubahan itu sendiri akan berlangsung secara cepat.

b. Tindakan yang diambil cenderung berdasarkan pilihan sendiri.

c. Kehidupan masyarakatnya cenderung lebih kepada individualistis.

d. Prestasi yang diperoleh lebih dihargai dengan materi.

e. Mobilitas yang terjadi di dalam masyarakat lebih tinggi.

f. Berorientasi pada karier dan aktualisasi diri (Noormondhawati 2013).

Bila dikaitkan dengan pendidikan, maka modernisasi tidak pernah dapat terlepas dari bentuk-bentuk kemajuan ilmu pengetahuan dan teknologi yang tengah berlangsug besar-besaran di dunia Barat. Ditambah dengan faktor lain yang mempengaruhi terjadi pembaharuan itu sendiri, yang terdapat pada berbagai bidang, seperti politik dan sosial. Sehingga pendidikan juga tidak dapat terlepas dari pengaruh terjadinya pembaharuan terutama dalam pemikiran pendidikan Islam, yang diawali dengan munculnya pembaharuan pemikiran pendidikan Islam di Mesir, Turki, India, dan lainnya.

Gagasan mengenai modernisasi dalam pemikiran Islam berasal dari gagasan tentang keinginan melakukan "modernisasi" pada pemikiran dan institusi Islam secara keseluruhan. Sehingga "modernisasi" yang terjadi dalam pendidikan Islam tidak terpisahkan dari kebangkitan gagasan program modernisasi Islam, yang menjadi kerangka dasar di balik "modernisasi" pemikiran dan kelembagaan Pendidikan islam yang merupakan prasyarat bagi kebangkitan umat Muslim di masa modern. Karenanya pendidikan Islam harus mengalami modernisasi, atau sederhananya diperbaharui sesuai dengan "modernitas". Dengan tetap mempertahankan pemikiran lembaga Islam "tradisional" akan memperpanjang ketidak berdayaan kaum Muslimin dalam menghadapi kemajuan di dunia modern.(Surya 2020).

Demi terwujudnya modernisasi pendidikan Islam maka masalah yang pertama haruslah menghapus dikotomi dalam dunia pendidikan. Masalah ini merupakan sebuah masalah klasik dimana terjadinya dikotomi pada dualisme ilmu, yaitu ilmu agama dan ilmu umum yang menunggu untuk segera dituntaskan, baik itu pada tingkatan filosofis-pragmatik maupun sampai pada tingkatan teknik departemen.

\section{Dalam pengembangan pendidikan} Islam dilakukan segala upaya menuju 
integrasi antara ilmu pengetahuan agama, dan ilmu pengetahuan umum, sehingga tidak ada lagi jurang pemisah antara keduanya. Sebab dalam pandangan Islam, ilmu pengetahuan hanyalah satu, itulah ilmu pengetahuan yang berasal dari Allah SWT. Begitu pula Soekarno yang memandang nondikotomi untuk dualisme pendidikan Islam dan pendidikan umum. Beliau menyerukan Islam Science, pandangannya mengenai Al-Qur'an dan Hadits yang mewajibkan kita menjadi cakrawati dilapangan secaga science dan progress, dilapangan segala pengetahuan dan kemajuan (Surya 2020).

\section{METODE PENELITIAN}

Penelitian ini menggunakan desain penelitian kualitatif. Penelitian kualitatif merupakan sebuah prosedur pelaksanaan penelitian yang didalamnya menggunakan data-data deskriptif baik itu berupa kata-kata tertulis dari orang atau pun pelaku yang tengah diamati. Kualitatif sendiri memiliki arti sesuatu yang berkaitan dengan kualitas, nilai atau makna yang terkandung dalam sebuah fakta, ketiganya diungkapkan melalui linguistik, bahasa maupun juga kata-kata (Fitrah, 2017).

Penelitian ini merupakan penelitian kepustakaan (library research). Menurut George dalam Patrisius Istiarto Djiwandono, penelitian kepustakaan atau yang lebih dikenal dengan studi pustaka merupakan penelitian yang menitikberatkan kepada pencarian sumber-sumber atau opini pakar mengenai suatu hal yang berkaitan dengan penelitian yang dilakukan. Dapat pula dikatakan bahwa studi pustaka adalah pengkajian sumber-sumber yang umumnya terdapat di dalam perpusatakaan yang ada kaitannya dengan variabel-variabel yang diangkat dalam sebuah penelitian (Djiwandono 2015).

Penelitian ini menggunakan dua sumber data yaitu sumber data yang bersifat primer dan sumber data yang bersifat sekunder. Menurut Bagja Waluya sumber data primer merupakan data-data atau keterangan yang didapatkan secara langsung dari sumber utamanya. Sedangkan sumber data sekunder merupakan sebutan untuk data atau keterangan yang diperoleh dari pihak kedua atau bukan pihak pertama, baik itu berasal dari orang atau catatan yang berupa buku, laporan, buletin, atau pun majalah yang sifatnya adalah dokumentasi (Waluya 2014).

Teknik analisis data yang digunakan dalam penelitian ini adalah teknik analisis data yang dipopulerkan oleh Miles dan Huberman dikutip dari Manik, dimana analisisnya dilakukan secara terus-menerus dan interaktif hingga sampai di titik jenuh, analis data yang dimaksud dengan analisis data deskriptif. Maksudnya penggambaran terhadap data-data pustaka yang memiliki hubungan dengan konteks penelitian. 
Analisis deskriptif, menganlisis dengan cara menggambarkan secara nyata dalam hal ini bisa saja bersifat deduktif, bisa saja bersifat induktif. Bersifat deduktif berarti bermula dari hal-halyang bersifat umum lalu di tarik satu kesimpuan khusus, sedangkan induktif kebalikannya. (Mamik 2015).

\section{HASIL DAN PEMBAHASAN}

Hasil penelitian dan pembahasan akan disajikan berdasarkan tujuan penelitian sebagaimana yang telah disebutkan pada bagian pendahuluan.

\section{Pendidikan Islam Menghadapi Tradisi}

Dalam kehidupan masyarakat, terutama masyarakat Indonesia dalam kehidupan sehari-harinya kerap terdengar istilah tradisi, seperti ungkapan tradisi Jawa, tradisi Keraton, tradisi tujuh bulanan, dan lain sebagainya.

Tradisi ini merujuk pada nilai, norma, dan adat istiadat yang telah lama dijalani, namun masih tetap diterima, diikuti bahkan dipertahankan oleh masyarakat atau kelompok sosial tertentu hingga saat ini (Bawani 1993).

Beberapa contoh tradisi yang lekat di dalam masyarakat Indonesia adalah:

a. Bila kita lihat, hampir semua kasus yang berkaitan dengan tragedi kemanusiaan di Indonesia tidak kunjung tuntas, mungkin karena dipetieskan, terkesan di tutup-tutupi, deperdagangkan dengan konsesikonsesi politik-ekonomi, atau pun karena adanya intervensi berbagai pihak yang dominan dibaliknya, termasuk para investor asing. Bila kita mau lebih jauh memperhatikan fenomena ini, ada benang merah dengan "teologi kekuasaanvoluntarisme" yang sepertinya sudah menjadi tradisi umai Islam dan diajarkan secara turun-temurun di Indonesia. Teologi ini menjadi lahan subur bagi penguasa untuk mengelabui rakyat dengan mengatasnamakan kehendak Tuhan terhadap perilakunya yang hegemonik. Teologi ini digunakan para penguasan untuk memaksa rakyat percaya bahwa situasi yang ada harus diterima karena merupakan takdir dari Tuhan, inilah yang disebut takdir dan nasib oleh mereka.

b. Kalangan umat Islam Indonesia yang memandang rendah dan kurang bergairah pada tradisi intelektual, wacana ilmiah, dan etos keilmuan pada lembaga pendidikan.

c. Adanya kebiasaan berpola pikir "pilih Tuhan atau pilih manusia" di kalangan umat Islam. Lalu umat Islam dengan teologi formal tradisional akan memilih Tuhan dengan cara menafikan manusia, yang berakibat pada rendahnya apresiasi terhadap 
pengembangan SDM. Maka tidak heran apabila kegiatan yang dianggap melayani Tuhan memiliki apresiasi yang sangat tinggi, seperti "Musabaqah Tilawatif Qur'an”, acara “maulidan”, "rajaban", "istighâtsah", membangun masjid, dan lain sebagainya. Namun kegiatan yang berkaitan dengan kemanusiaan seperti pengembangan sumber daya manusia, pemberian beasiswa, dan pembagunan lembaga pendidikan kurang mendapat apresiasi.

d. Terdapat tradisi pembelaan diri dengan jalan mengalihkan permasalahan yang ada kepada Tuhan atau penguasa. Hal ini sering kita dengar di kalangan masyarakat kita, dimana pejabat akan mengatakan: "kami kan manusia biasa, wajar kami melakukan kesalahan, hanya Tuhan yang dapat menyelesaikan permasalahan di negeri ini". Padahal ini merupakan ucapan perlindungan diri di bawah nama Tuhan untuk melindungi kesalahan yang telah diperbuat, atau atas nama makhluk yang hina penuh dosa (sambil menyebut Tuhan yang Maha Suci) untuk membersihkan diri.

e. Di Indonesia terdapat tradisi slametan untuk Nyi Roro Kidul, Dewi Sri, membaca jampi-jampi, dan ada pula tradisi untuk membuat, menonton, dan menceritakan hal-hal di luar akal manusia, seperti film yang menceritakan tentang tuyul, tokohtokoh jin, manusia super, lampu aladdin yang semuanya berisikan khayalan, imajinasi, dan mimpi-mimpi kosong. Lantaran pola pikir ini kegiatan-kegiatan seperti arisan berantai, judi, klenik, pelet, pesugihan, mendatangi dukun dan hal-hal di luar akal sehat manusia menjadikan umat Islam selalu dipenuhi dengan khayalan-khayalan yang irrasional dan terlalu takut menghadapi kenyataan yang ada (Thonthowi 2008).

Beberapa contoh tradisi yang peneliti sebutkan diatas, haruslah mampu untuk dihadapi dan ditanggulangi oleh pendidikan Islam modern.

Dimana pembelajaran harus mampu mengarahkan masyarakat untuk memilah dan memilih tradisi yang sesuai dengan ajaran Islam yang berpatokan kepada AlQur'an dan Hadits. Menurut peneliti ada beberapa hal yang dapat dilakukan oleh lembaga pendidikan Islam agar mampu menghadapi tradisi yang lekat di dalam masyarakat yaitu:

a. Pendidikan Islam harus mampu mengajarkan ketaatan dalam beribadah secara maksimal, agar masyarakat dapat sedikit demi sedikit mengetahui dan mempelajari apa-apa 
saja tradisi yang tidak sesuai dengan ajaran Islam.

b. Pendidikan Islam harus mampu memberikan pengajaran berupa penerimaan atas kondisi materiil yang relatif serba kekurangan. Karena biasanya tradisi yang bertentangan dengan agama itu terjadi sebagian besar karena masalah ekonomi. Seperti pesugihan yang dilakukan untuk mendapatkan harta kekayaan yang berlimpah. Disinilah peran pendidikan Islam yang sesungguhnya untuk memberikan pengajaran mengenai penerimaan terhadap kondisi materiil masyarakat, dan pemberian solusi berupa pengajaran untuk bekerja keras, berdoa dan bertawakal kepada Tuhan yang Maha Esa jika masalah yang ingin diselesaikan adalah ingin menjadi kaya atau berkecukupan dalam segi financial.

c. Pendidikan Islam harus mampu untuk meningkatkan kesadaran terhadap lingkungan. Karena ketika masing-masing masyarakat saling mempedulikan lingkungan sekitarnya, maka besar kemungkinan untuk satu sama lain saling mengingatkan terkait dengan tradisitradisi yang bertentangan dengan agama.

\section{Pendidikan Islam Menghadapi Transisi}

Seperti yang telah dijelaskan sebelumnya bahwa transisi adalah sebuah peralihan dari suatu keadaan kepada keadaan lainnya.

Terutama dalam bidang pendidikan, transisi ini terjadi untuk menuju Indonesia yang berpendidikan, berpengetahuan luas dan dapat menentukan arah ke mana Indonesia ini akan berkembang nantinya. Terutama yang berkaitan dengan pendidikan Islam. Sehingga mulai maraklah inovasiinovasi yang dilakukan di dalam bidang pendidikan Islam yang dilakukan di masjidmasjid, pondok pesantren, dan lembaga pendidikan Islam dengan harapan agar dapat terjadi peralihan atau transisi dalam bidang pendidikan Islam menuju arah yang lebih baik.

Peneliti mencoba mengaitkan masalah transisi ini dengan masalah pandemi yang tengah menjadi masalah bagi masyarakat dunia. Dimana secara tidak langsung lembaga pendidikan Islam dan umum di haruskan siap dalam menghadapi hal ini. Dimana salah satu bentuk perubahan yang terjadi adalah perubahan atau peralihan pembelajaran yang sebelum pandemi dilakukan dengan tatap muka, berubah sistem menjadi pendidikan berbasis daring.

Lembaga pendidikan Islam haruslah mempersiapkan diri dengan segala bentuk transisi yang terjadi, transisi yang tengah 
terjadi pada saat ini adalah peralihan dari pembelajaran di kelas menjadi pembelajaran secara online. Bila lembaga pendidikan tidak mempersiapkan diri untuk ini, tentu lembaga pendidikan Islam akan ketinggalan dibandingkan dengan lembaga pendidikan umum serta tidak dapat melaksanakan pembelajaran dengan sebaik-baiknya.

Untuk menghadapi transisi atau peralihan ini, peneliti memberikan beberapa solusi untuk menghadapi transisi ini, yaitu:

a. Kepala sekolah selaku pemangku jabatan tertinggi di sekolah harus mampu untuk menyediakan dana dan fasilitas untuk kemungkinankemungkinan terjadinya transisi atau peralihan-peralihan bidang pendidikan di masa depan. Sebagai contoh apabila terjadi pandemi dan pembelajaran harus dilaksanakan dari rumah, maka kepala sekolah harus mendanai bahkan lebih baik lagi bila mampu memfasilitasi segala bentuk kebutuhan mengajar virtual bagi pendidik dalam melaksanakan pembelajaran secara online. Agar pembelajaran secara online tetap dapat terlaksana dengan baik dan murid tetap mendapatkan ilmu pengetahuan yang harusnya memang mereka dapatkan.

b. Lembaga pendidikan Islam harus menyediakan pelatihan penggunaan teknologi kepada pendidik, agar tidak ada pendidik yang gaptek (gagap teknologi) apabila sewaktu-waktu dibutuhkan untuk menggunakan teknologi di waktu-waktu yang mendesak, bagi semua mata pelajaran dan jenjang pendidikan.

c. Lembaga pendidikan Islam harus memotivasi pendidik untuk mengenal dan mempelajari penggunaan teknologi yang berguna untuk pelaksanaan kegiatan pembelajaran, karena itu adalah hal yang mutlak untuk dikuasai oleh pendidik di masa kini.

d. Lembaga pendidikan Islam harus memotivasi pendidik untuk melakukan inovasi-inovasi pembelajaran kepada peserta didiknya, sehingga bukan hanya membebani mereka dengan pekerjaan rumah namun juga pengetahuan dan keterampilan yang akan berguna bagi kehidupan bermasyarakat mereka nantinya.

e. Lembaga pendidikan Islam harus mengembangkan konsep pembelajaran mandiri, dengan cara mengajak orang tua siswa berdiskusi dan menjadi fasilitator dan educator di rumah, sehingga pembelajaran tidak hanya terjadi disekolah saja namun juga dirumah, sehingga apa yang dipelajari akan lebih mudah untu diserap oleh siswa. 
f. Lembaga pendidikan Islam harus melakukan pengawasan, terhadap tugas dan tanggung jawab setiap warga sekolah, dengan memastikan bahwa pembelajaran terjadi dengan baik, karena apapun transisi dan peralihan yang terjadi, yang terpenting adalah memastikan bahwa pembelajaran itu terjadi secara baik dan berhasil kepada seluruh peserta didik.

\section{Pendidikan Islam Menghadapi} Modernisasi

Modernisasi adalah sebuah keadaan dimana sesuatu berjalan menjadi lebih baik dari sebelumnya.

Modernisasi merupakan sebuah keadaan dimana didalamnya melibatkan perubahan dalam sistem sosial yang sifatnya berlangsung secara terus-menerus (immament). Sekali terjadi perubahan sosial di satu bidang, itu akan memicu perubahan di bidang yang lainnya, untuk itu, teori modernisasi cenderung memandang bahwa proses perubahan terjadi karena faktor dalam (internal resources), bukan faktor dari luar (eksternal resources) (Danial 2009).

Dalam kaitannya dengan pendidikan, modernisasi di dalam pendidikan menjadi proses multi-dimensional yang kompleks, dan ditujukan tidak hanya pada penyempurnaan kelemahan-kelemahan pendidikan, lebih jauh dari itu, modernisasi pendidikan juga ditujukan untuk merumusan tujuan, visi, misi baru, yang pada orientasinya selalu berakar pada kebutuhan dan perubahan yang terjadi dalam masyarakat. Upaya ini akan terus berlangsung sepanjang zaman, karena modernisasi akan menggiring perkembangan teknologi kepada persaingan tingkat global, yang berarti efektivitas dan efisiensi merupakan pilihan yang paling utama dalam pelaksanaannya (Takdir 2018).

Menurut peneliti, modernisasi diperlukan dalam pendidikan Islam agar pendidikan Islam dapat mengikuti perkembangan zaman sehingga tujuan utama pendidikan Islam itu sendiri dapat tercapai dengan tetap mengikuti tuntutan perkembangan zaman.

Modernisasi pendidikan Islam adalah sesuatu yang tidak dapat dielakkan. Merupakan sebuah persoalan yang membutuhkan waktu sepanjang hayat untuk terus mengikuti perkembangan modernisasi itu sendiri.

Menurut peneliti, dalam menghadapi modernisasi yang terjadi dalam pendidikan Islam, lembaga pendidikan Islam dapat melakukan beberapa hal, yaitu:

a. Tetap selalu menjaga nilai-nilai dan prinsip serta karakteristik pendidikan Islam dengan tetap mengarahkan pembelajaran untuk keberhasilan pendidikan Islam.

b. Lembaga pendidikan Islam harus melakukan inovasi terkait dengan kurikulum pembelajaran. Dimana 
menurut peneliti, pembelajaran di dalam lembaga pendidikan Islam haruslah mampu untuk memenuhi kebutuhan peserta didik dalam mempelajari pengetahuan umum dan pengetahuan agama. Sehingga tidak ada lagi orang tua yang akan merendahkan lembaga pendidikan Islam karena kurangnya pembelajaran agama.

c. Lembaga pendidikan Islam harus melakukan inovasi pada metode pembelajaran. Menurut peneliti, metode pembelajaran konvensional seperti ceramah tidaklah buruk, namun pendidikan harus memberikan inovasi dengan lebih banyak memberikan peserta didik untuk menemukan sendiri solusi dari masalah yang ia temukan sehingga apa yang ditemukannya akan lebih lama tersimpan di dalam memorinya.

d. Lembaga pendidikan Islam harus lebih meningkatkan kedisiplinan. Menurut peneliti, beberapa lembaga pendidikan Islam kurang melatih kedisiplinan siswanya sehingga orang tua kerapkali lebih menyukai lembaga pendidikan umum karena merasa lembaga pendidikan Islam kurang ketat dalam memberikan peraturan kepada siswanya. Hal ini dapat dimulai dengan memberikan peraturan berupa larangan mengenakan aksesoris di dalam sekolah, serta pemberian sanksi kepada siswa yang berani melanggar peraturan. Karena di era modern seperti sekarang, orang tua cenderung lebih mempercayai sekolah yang ketat dalam memberikan peraturan kepada siswanya agar anaknya dapat diajarkan disiplin di dalam sekolah tempatnya belajar.

e. Lembaga pendidikan Islam harus memberikan biaya pendidikan yang tidak terlalu tinggi namun berkualitas sehingga peserta didik dari semua kalangan dapat merasakan pendidikan di lembaga pendidikan Islam tersebut namun dengan kualitas yang tidak kalah dari lembaga pendidikan umum.

f. Lembaga pendidikan Islam harus mampu melahirkan generasi intelektual namun tetap sesuai dengan kebutuhan masyarakat. Karena di era globalisasi ini, yang diharapkan oleh seluruh peserta didik di dalam lembaga pendidikan, adalah memiliki skill yang cukup untuk mampu bersaing di dalam dunia kerja selepas menyelesaikan pendidikan.

g. Lembaga pendidikan Islam harus mampu melahirkan tamatan yang tidak memikirkan diri sendiri, disiplin, jujur, serta bertakwa kepada Allah SWT. 


\section{SIMPULAN}

Untuk menjawab pertanyaan awal dimana peneliti berusaha mengetahui bagaimana pendidikan Islam menghadapi tradisi, transisi dan modernisasi, melalui penelitian pustaka yang telah peneliti lakukan, maka peneliti menyimpulkan:

Untuk menghadapi masalah yang berkaitan dengan tradisi, beberapa hal yang harus dilakukan adalah: 1) pendidikan Islam harus mampu mengajarkan ketaatan dalam beribadah secara maksimal, 2) pendidikan Islam harus mampu memberikan pengajaran berupa penerimaan atas kondisi materiil yang relatif serba kekurangan, 3) pendidikan Islam harus mampu untuk meningkatkan kesadaran terhadap lingkungan.

Untuk menghadapi masalah yang berkaitan dengan transisi atau peralihan, beberapa hal yang harus dilakukan adalah: 1) kepala sekolah selaku pemangku jabatan tertinggi di sekolah harus mampu untuk menyediakan dana dan fasilitas untuk kemungkinan-kemungkinan terjadinya transisi atau peralihan-peralihan bidang pendidikan di masa depan, 2) lembaga pendidikan Islam harus menyediakan pelatihan penggunaan teknologi kepada para pendidik, 3) lembaga pendidikan Islam harus memotivasi pendidik untuk mengenal dan mempelajari penggunaan teknologi yang berguna untuk pelaksanaan kegiatan pembelajaran, 4) lembaga pendidikan Islam harus memotivasi pendidik untuk melakukan inovasi-inovasi pembelajaran kepada peserta didiknya, 5) lembaga pendidikan Islam harus mengembangkan konsep pembelajaran mandiri, dengan cara mengajak orang tua siswa berdiskusi dan menjadi fasilitator dan educator di rumah, sehingga pembelajaran tidak hanya terjadi disekolah saja namun juga dirumah, dan 6) lembaga pendidikan Islam harus melakukan pengawasan, terhadap tugas dan tanggung jawab setiap warga sekolah, dengan memastikan bahwa pembelajaran terjadi dengan baik.

Untuk menghadapi masalah yang berkaitan dengan modernisasi, beberapa hal yang harus dilakukan adalah: 1) Tetap selalu menjaga nilai-nilai dan prinsip serta karakteristik pendidikan Islam dengan tetap mengarahkan pembelajaran untuk keberhasilan pendidikan Islam, 2) lembaga pendidikan Islam harus melakukan inovasi terkait dengan kurikulum pembelajaran, 3) lembaga pendidikan Islam harus melakukan inovasi pada metode pembelajaran, 4) lembaga pendidikan Islam harus lebih meningkatkan kedisiplinan, 5) lembaga pendidikan Islam harus memberikan biaya pendidikan yang tidak terlalu tinggi namun berkualitas sehingga peserta didik dari semua kalangan dapat merasakan pendidikan di lembaga pendidikan Islam, 6) lembaga pendidikan Islam harus mampu melahirkan generasi intelektual namun tetap sesuai dengan kebutuhan masyarakat, dan 7) 
lembaga pendidikan Islam harus mampu melahirkan tamatan yang tidak memikirkan diri sendiri, disiplin, jujur, serta bertakwa kepada Allah SWT.

\section{DAFTAR PUSTAKA}

Amin, A. Rifai. 2015. Pengembangan Pendidikan Agama Islam: Reinterpretasi Berbasis Interdisipliner. Yogyakarta: LKiS Pelangi Aksara.

Azra, Azyumardi. 2012. Pendidikan Islam: Tradisi Dan Modernisasi Di Tengah Tantangan Milenium III. Jakarta: Kencana.

Bawani, Imam. 1993. Tradisionalisme Dalam Pendidikan Islam: Studi Tentang Daya Tahan Pesantren Tradisional. Surabaya: alIkhlas.

Danial, Akhmad. 2009. Iklan Politik TV: Modernisasi Kampanye Politik Pasca Orde Baru. edited by A. Arifin. Yogyakarta: LKiS Yogyakarta.

Djiwandono, Patrisius Istiarto. 2015. Meneliti Itu Tidak Sulit: Metodologi Penelitian Sosial Dan Penelitian Babasa. Yogyakarta: Deepublish.

Feisal, Jusuf Amir. 1995. Reorientasi Pendidikan Islam. 1st ed. Jakarta: Gema Insani Press.

Fitrah, Muh dan Luthfiyah. 2017. Metodologi Penelitian; Penelitian Kualitatif, Tindakan Kelas \& Studi Kasus. edited by Ruslan dan Moch. Mahfud Effendi. Sukabumi: CV Jejak.

Indrioko, Erwin. 2016. "Lembaga Pendidikan Islam Dalam Menghadapi Derasnya Perubahan." An-Nuba 3(1):61-76.

Kholik, Nur dkk, 2020. Never Dies: Alternative Islamic Education (Internalisasi Nilai-Nilai Pendidikan Islam Dalam Ruang Publike). edited by A. Zubaidi. Tasikmalaya: Edu Publisher.

Mamik. 2015. "Metodologi Kualitatif." Zifatama Publisher 153-54.
Maryati, Kun dan Juju Suryawati. 2007. Sosiologi Untuk SMA Dan MA Kelas XII. edited by R. Genggor. Jakarta: Esis.

Neolaka, Amos dan Grace Amialia A. Neolaka. 2017. Landasan Pendidikan: Dasar Pengenalan Diri Sendiri Menuju Perubahan Hidup. Depok: Kencana.

Nofrita, Misra dan Delia Putri. 2019. Tradisi Lisan: Bahasa Dan Sastra Budaya Rokan. 1st ed. edited by Q. Media. Pasuruan: CV. Penerbit Qiara Media.

Noormondhawati, Lely. 2013. Islam Memuliakanmu, Saudariku. 1st ed. Jakarta: PT.Elex Media Komputindo.

Simanjuntak, Bungaran Antonius. 2016. Tradisi, Agama, dan Akseptasi Modernisasi Pada Masyarakat Pedesaan Jawa. 1st ed. Jakarta: Yayasan Pustaka Obor Indonesia.

Sugono, Dendy dkk,. 2019. Kamus Bahasa Indonesia Sekolah Dasar. Jakarta: PT Gramedia Pustaka Utama.

Surya, Lukman dan Nur Kholik. 2020. Manifesto Modernisasi Pendidikan Islam: Ulasan Pemikiran Soekarno. edited by E. F. F. Khomaeny. Tasikmalaya: Edu Publisher.

Takdir, Mohammad. 2018. Modernisasi Kurikulum Pesantren. edited by Yanuar dan Yudi. Yogyakarta: IRCiSoD.

Thonthowi. 2008. "Pendidikan Dan Tradisi (Menakar Tradisi Pendidikan Pesantren)." Tadris Vol 3 No 2:150-65.

Tjaya, Th. Hidya dan J. Sudarminta, ed. 2005. Menggagas Manusia Sebagai Penafsir. 1st ed. Yogyakarta: Kanisius.

Tolchah, Moch. 2015. Dinamika Pendidikan Islam Pasca Orde Baru. edited by C. Wahyudi. Yogyakarta: LKiS Pelangi Aksara.

Waluya, Bagja. 2014. Sosiologi: Menyelami Fenomena Sosial Di Masyarakat. Rineka Cipta 